\title{
Bioaccumulation of Heavy Metals in Different Tissues of Lamellidens corrianus from Krishna River at Ankali, Maharashtra (India)
}

\author{
S. A. Manjare \\ Department of Zoology, Jaysingpur College, Jaysingpur
}

\begin{abstract}
The present study deals with the bioaccumulation of heavy metals in the freshwater lamellibranch mollusks inhabiting in the Krishna river at Ankali. The bivalve, Lamellidens corrianus (Lea), was selected in the present study. This species of mollusks was subjected for detection of heavy metals such as Zinc, Nickel, Lead and Aluminium from various soft tissues such as mantle, gill, siphon, foot, hepatopancreas and gonads. The work was carried out seasonally for the period from January 2013 to December 2013 and values were recorded in ppm. In general, accumulation of $\mathrm{Zn}$ was maximum in gills, while minimum in foot in different seasons. Similarly accumulation of $\mathrm{Ni}, \mathrm{Pb}$ and $\mathrm{Al}$ was maximum in gonads whereas, it was minimum in siphon in different seasons.
\end{abstract}

Keywords: Bioaccumulation, Heavy metals, tissues, L. corrianus, Krishna River

\section{Introduction}

With an early use of metals, there was little concern about environmental contamination. The salts of metals were utilizing into commercial and industrial applications. Then it becomes evident that, metallic salts possess certain biocidal properties. In the last few years there has been a great deal of concern about heavy metal pollution. Effects of metals on different organisms are reported by many workers. A great deal of research still has to be done on the effects of metals on different organisms. The invertebrates appear to have a particularly high capability for concentrating metals along with other foreign materials found in their environment.

In India, wide use of metals in different chemical forms by the industrial, agricultural and domestic sectors has resulted in a great deal of concern about the release of toxic metals in the environment. Increasing awareness of ecological hazards to human life arising from the discharge of toxic metals from urban and industrial sources has involved considerable interest in the study of levels and fate of metals in the aquatic environment.

The present study deals with the bioaccumulation of heavy metals in the freshwater lamellibranch mollusks inhabiting in the Krishna river at Ankali. The bivalve, Lamellidens corrianus (Lea), was selected in the present study. This species of mollusks was subjected for detection of heavy metals such as Nickel, Zinc, Lead and Aluminium from various soft tissues such as mantle, gill, siphon, foot, hepatopancreas and gonads.

\section{Material and Methods}

The present investigation was carried out during the year January 2013 to December 2013. Monthly analysis was carried out for all heavy metals and rectified to the seasonal basis. The bivalve species inhabiting along the bank of Krishna River at Ankali, which was selected for present study. The shell length of bivalve Lamellidens corrianus was ranged from $9.5 \mathrm{~cm}$. to $10.5 \mathrm{~cm}$. The species was collected and brought to laboratory and cleaned to remove the fouling algal mass and mud. The bivalves were then stocked in tap water for few hours. The Shells were removed and the soft animals were taken in a tray. Various tissues of bivalve mollusks such as mantle, gill, siphon, foot, hepatopancreas and gonads were removed separately. These tissues were oven dried at $60^{\circ} \mathrm{C}$ for 48 hours. Dried tissues were pulverized in mortar and kept in polyether bags and stored in the refrigerator. The powdered sample was analyzed for detection of heavy metals.

The powdered tissue were digested in $10 \mathrm{ml}$. Perchloric acid and Nitric acid in 1:1 ratio (Lithnor, 1975). The digested tissue solution was filtered and these samples were analyzed for detection of heavy metals by using atomic absorption / emission spectrophotometer (Chemito, 201) and the values were expressed in ppm.

\section{Result and Discussion}

\section{Winter}

The detection of metals $(\mathrm{Zn}, \mathrm{Ni}, \mathrm{Pb}$ and $\mathrm{Al})$ from bivalve mollusks of different species was carried out. At station Ankali the metal content during winter season (January) from the bivalve tissues (L. corrianus) was estimated as the zinc content in different tissues was in the order of gill $>$ gonads $>$ mantle $>$ hepatopancreas $>$ siphon $>$ foot $(0.65$, $0.56,0.42,0.19,0.16,0.09 \mathrm{ppm}$ respectively). The Nickel content in different tissues was in the order of gonads $>$ hepatopancreas $>$ mantle $>$ gill $>$ foot $>$ siphon $(0.661$, $0.553,0.497,0.483,0.083,0.008 \mathrm{ppm}$ respectively). The Lead concentration in different tissues was in the order of gonads $>$ hepatopancreas $>$ mantle $>$ gill $>$ foot $>$ siphon (0.094, 0.088, 0.082, 0.081, 0.062, $0.006 \mathrm{ppm}$ respectively). The Aluminium content in different tissues was in the order of gonads $>$ hepatopancreas $>$ gill $>$ foot $>$ siphon $>$ mantle $(0.221,0.123,0.112,0.081,0.062,0.061 \mathrm{ppm}$ respectively).

Comparatively maximum concentration of heavy metals in different tissues of bivalve molluscs ( $L$. corrianus) was observed during winter season (January). The zinc content 


\section{International Journal of Science and Research (IJSR) \\ ISSN (Online): 2319-7064}

Index Copernicus Value (2013): 6.14 | Impact Factor (2014): 5.611

was maximum $(0.65 \mathrm{ppm})$ in gill and minimum $(0.09 \mathrm{ppm})$ in foot. Whereas nickel content was maximum (0.661 ppm) in gonads and minimum $(0.0008 \mathrm{ppm})$ in siphon, lead content was maximum $(0.221 \mathrm{ppm})$ in gonad and minimum $(0.061 \mathrm{ppm})$ in siphon and mantle. Aluminium content was maximum $(0.221 \mathrm{ppm})$ in gonad and minimum $(0.062 \mathrm{ppm})$ in siphon.

The accumulation of metals varies from metal to metal and differs among

\section{Summer}

At station Ankali the metal content during summer season (May) from the bivalve tissues (L. corrianus) was estimated as under. The zinc content in different tissues was in the order of gill $>$ gonads $>$ mantle $>$ siphon $>$ hepatopancreas $>$ foot $(0.76,0.337,0.33,0.285,0.22,0.13 \mathrm{ppm}$ respectively). The Nickel content in different tissues was in the order of gonads $>$ hepatopancreas $>$ mantle $>$ gill $>$ foot $>$ siphon ( $0.661,0.553,0.497,0.483,0.083,0.008$ ppm respectively). The Lead concentration in different tissues was in the order of gonads $>$ hepatopancreas $>$ mantle $>$ gill $>$ foot $>$ siphon (0.67, 0.51, 0.493,0.441, 0.079, 0.009 ppm respectively). The Aluminium content in different tissues was in the order of gonads $>$ hepatopancreas $>$ mantle $>$ gill $>$ siphon $(0.200$, $0.109,0.083,0.061,0.003 \mathrm{ppm}$ respectively).

The metal content during summer season (May) from bivalve tissue (L. corrianus) was studied. The zinc content was maximum $(0.6 \mathrm{ppm})$ in gill and minimum $(0.13 \mathrm{ppm})$ in foot. Whereas nickel content was maximum $(0.67 \mathrm{ppm})$ in gonads and minimum $(0.009 \mathrm{ppm})$ in siphon, lead content was maximum (0.089 ppm) in gonad and minimum (0.009 $\mathrm{ppm})$ in siphon. Aluminium content was maximum $(0.200$ $\mathrm{ppm})$ in gonad and minimum $(0.003 \mathrm{ppm})$ in siphon.

\section{Monsoon}

At station Ankali the metal content during monsoon season (July) from the bivalve tissues (L. corrianus) was estimated as under. The zinc content in different tissues was in the order of gill $>$ siphon $>$ mantle and hepatopancreas $>$ foot $>$ gonads $(0.875,0.410,0.225,0.175,0.115 \mathrm{ppm}$ respectively). The Nickel content in different tissues was in the order of gonads $>$ hepatopancreas $>$ mantle $>$ gill $>$ foot $>$ siphon (0.692, 0.540, 0.489, 0.400, 0.076, 0.10 ppm respectively). The Lead concentration in different tissues was in the order of gonads $>$ hepatopancreas $>$ mantle $>$ foot $>$ gill $>$ siphon $(0.089,0.090,0.078,0.070,0.067,0.004 \mathrm{ppm}$ respectively). The Aluminium content in different tissues was in the order of gonads $>$ hepatopancreas $>$ gill $>$ foot $>$ mantle $>$ siphon $(0.204, \quad 0.099, \quad 0.098, \quad 0.084, \quad 0.064,0.0042$ ppm respectively).

The metal content during monsoon season (July) from bivalve tissue (L. corrianus) was studied. The zinc content was maximum $(0.875 \mathrm{ppm})$ in gill and minimum $(0.115$ ppm) in gonad. Whereas nickel content was maximum $(0.692 \mathrm{ppm})$ in gonads and minimum $(0.010 \mathrm{ppm})$ in siphon, lead content was maximum $(0.090 \mathrm{ppm})$ in gonad and minimum $(0.004 \mathrm{ppm})$ in siphon. Aluminium content was maximum $(0.204 \mathrm{ppm})$ in gonad and minimum $(0.0042$ ppm) in siphon.

\section{Conclusion}

The bivalve tissues like mantle, gill, foot, siphon, hepatopancereas and gonads of bivalve species Lamelliden corrianus showed typical pattern of accumulation. In general, accumulation of $\mathrm{Zn}$ was maximum in gills, while minimum in foot in different seasons. Similarly accumulation of $\mathrm{Ni}, \mathrm{Pb}$ and $\mathrm{Al}$ was maximum in gonads whereas, it was minimum in siphon in different seasons.

Table 1: Heavy metal concentrations in Bivalve tissues (in ppm) from Krishna river at Station Ankali (January 2013 to

December 2013)

\begin{tabular}{|c|c|c|c|c|c|}
\hline \multicolumn{6}{|c|}{ Winter } \\
\hline Species & Tissues & Zinc & Nickel & Lead & Aluminium \\
\hline Lc & Mantle & 0.42 & 0.497 & 0.081 & 0.061 \\
\hline & Gill & 0.65 & 0.483 & 0.062 & 0.112 \\
\hline & Siphon & 0.16 & 0.008 & 0.006 & 0.062 \\
\hline & Foot & 0.09 & 0.082 & 0.082 & 0.081 \\
\hline & Heaptopancreas & 0.19 & 0.553 & 0.088 & 0.123 \\
\hline & Gonads & 0.56 & 0.661 & 0.094 & 0.221 \\
\hline \multicolumn{5}{|c|}{ Summer } \\
\hline & Mantle & 0.033 & 0.493 & 0.079 & 0.061 \\
\hline & Gill & 0.076 & 0.441 & 0.064 & 0.109 \\
\hline & Siphon & 0.285 & 0.009 & 0.005 & 0.003 \\
\hline & Foot & 0.13 & 0.079 & 0.076 & 0.083 \\
\hline & Heaptopancreas & 0.22 & 0.51 & 0.086 & 0.109 \\
\hline & Gonads & 0.337 & 0.67 & 0.089 & 0.200 \\
\hline \multicolumn{7}{|c|}{ Monsoon } \\
\hline & Mantle & 0.255 & 0.489 & 0.078 & 0.062 \\
\hline & Gill & 0.875 & 0.400 & 0.067 & 0.098 \\
\hline & Siphon & 0.410 & 0.010 & 0.004 & 0.004 \\
\hline & Foot & 0.175 & 0.076 & 0.070 & 0.084 \\
\hline & Heaptopancreas & 0.225 & 0.540 & 0.090 & 0.099 \\
\hline & Gonads & 0.115 & 0.692 & 0.089 & 0.204 \\
\hline
\end{tabular}

Lc - Lamellidens corrianus

\section{References}

[1] Ayyavoo, M. (1989): studies on the metal concentration on Cauvary River and Poompuhar East-coast Tamil Nadu. National Young Scientist Seminar on Environmental pollution. March 30-31, Page 10

[2] Ganesan, V. C. (1991):Trace metal concentration in water and sediment of the river Khan and Kshipra (Ujjain, India). Inter. J. Ecol. And Environ. Sci. 17: 225236.

[3] Kataria, H. C. (1994): Heavy metals contamination and pollution in Betwa River. JEP, 15 (1): 34-38.

[4] Lind, O. T (1974): Hand book of common methods in limnology. The C. V. Mosby Co., Saint Louis (USA).

[5] Lithnor, G. (1975): Methods for detection, measurement and monitoring of water pollution, FAO, Rome, PP 41.

[6] Mani, S. S., Sweth Aranyam and S. S. Daevi (1989): An increased level of trace metals in Pazhan Cauvery river water due to domestic sewage pollution. Seminar on Environmental pollution, 30 March, Bangalore.

[7] Moriarty, F. and H. M. Hanson (1989): Heavy metals in sediments of the river Ecchesbourne, Darbishire. Water resources, 22: 475-480.

[8] Trivedy and Goal (1987): Practical methods I Ecology and Environmental Science. 